\title{
PENERAPAN MODEL STUDENT TEAM ACHIEVEMENT DIVISION (STAD) DITINJAU DARI KEMAMPUAN BERPIKIR KREATIF SISWA PADA MATERI SEGIEMPAT
}

\author{
Aida Shofiyyatunnisa ${ }^{1}$, Heni Pujiastuti ${ }^{2}$ \\ Pendidikan Matematika ${ }^{1,2}$, Fakultas Keguruan dan Pendidikan ${ }^{1,2}$, Universitas \\ Sultan Ageng Tirtayasa ${ }^{1,2}$ \\ aidashofiyyatunnisa@gmail.com ${ }^{1}$
}

\begin{abstract}
Abstrak
Jenis penelitian ini adalah penelitian eksperimen semu yang bertujuan untuk mengetahui apakah penerapan model pembelajaran kooperatif tipe Student Team Achievement Division (STAD) dapat meningkatkan kemampuan berpikir kreatif matematika siswa kelas VII SMPN 1 KRAMATWATU pada materi segiempat. Penelitian ini menggunakan metode kuantitatif. Populasi pada penelitian ini adalah seluruh siswa kelas VIII SMPN 1 KRAMATWATU yang terdiri dari sembilan kelas dan dengan teknik purposive sampling terpilih dua kelas sebagai kelas sampel yaitu kelas VII D yang berjumlah 28 orang sebagai kelas eksperimen dan kelas VII E yang berjumlah 28 sebagai kelas kontrol. Pengumpulan data dilakukan dengan cara memberikan tes tertulis dalam bentuk soal-soal uraian (essay) sebanyak 5 soal. Berdasarkan hasil analisis data secara dekriptif diperoleh bahwa nilai rata-rata kemampuan berpikir kreatif siswa pada materi segiempat adalah 44,47 dari skor ideal 100 serta hasil rata-rata persentasenya adalah $44 \%$ berada pada kategori kurang kreatif artinya masih banyak siswa yang belum mampu untuk berpikir kreatif dalam memecahkan masalah pada materi segiempat. Namun, hasil penelitian ini menunjukkan bahwa peningkatan rata-rata kemampuan berpikir kreatif matematika siswa yang diajar dengan pendekatan STAD lebih baik dari pembelajaran konvensional.
\end{abstract}

Kata Kunci: Berpikir Kreatif, Matematika, Segiempat, STAD

\section{A. Pendahuluan}

Pendidikan adalah hal yang sangat penting dan dibutuhkan dalam kehidupan manusia terutama pada bangsa yang terus menerus berkembang, dimana manusia berhak mendapakan pendidikan dan mampu mengembangakan pendidikan tersebut sesuai dengan sumber daya dan pola pikir manusia yang berkualitas. Hal tersebut terdapat pada Undang-undang Nomor 20 Tahun 2003 pasal 1 ayat 1 tentang sistem pendidikan nasional, bahwa pendidikan adalah usaha sadar dan terencana untuk mewujudkan suasana belajar dan proses pembelajaran agar peserta didik secara aktif mengembangkan potensi dirinya untuk memiliki kekuatan spiritual keagamaan, pengendalian diri, kepribadian, kecerdasan, akhlak mulia, serta 
keterampilan yang diperlukan dirinya, masyarakat, bangsa, dan negara. Sehingga untuk dapat mencapai tujuan hidup tersebut harus dilakukan usaha yang diwujudkan dengan belajar.

Maka dari itu, diperlukan upaya pembelajaran yang optimal agar siswa dapat memahami materi pembelajaran dengan baik dan benar dan juga berbagai upaya telah dilakukan pemerintah untuk melakukan inovasi dalam dunia pendidikan, misalnya dengan memperkenalkan berbagai model pembelajaran inovatif, aktif dan kreatif. Pemerintah juga telah berupaya untuk melengkapi sarana dan prasarana pembelajaran, misalnya dengan menyediakan buku- buku gratis melalui program BSE (Buku Sekolah Elektronik). Serta profesionalisme guru juga telah ditingkatkan, misalnya melalui pemberian pelatihan tentang pembelajaran seperti seminar dan yang lainnya .

Matematika merupakan salah satu mata pelajaran yang mempunyai peranan penting dalam dunia pendidikan juga memiliki peranan penting dalam kehidupan sehari-hari dan tidak dapat ditinggalkan baik pada jenjang sekolah dasar, sekolah menengah sampai perguruan tinggi. Mata pelajaran Matematika perlu diberikan kepada semua peserta didik mulai dari sekolah dasar untuk membekali peserta didik dengan kemampuan berpikir logis, analitis, sistematis, kritis, dan kreatif, serta kemampuan bekerjasama (Chaeriyah, 2010). Mata pelajaran ini (matematika) diajarkan pada setiap jenjang pendidikan dan menjadi penentu syarat kelulusan pada jenjang SD, SMP dan SMA. Dikarenakan matematika merupakan salah satu pengetahuan yang paling bermanfaat dalam kehidupan (Rohmawati, 2017).

Pembelajaran matematika di sekolah tidak hanya berkaitan dengan penguasaan materi matematika sebanyak-banyaknya, namun juga untuk mencapai tujuantujuan yang lebih tinggi misalnya mengembangkan kemampuan berpikir siswa (Widi Trisna Putri \& Ratu, 2018). Hal ini terbukti adanya Peraturan Pemerintah Nomor 17 Tahun 2010 dalam Kurikulum 2013 tentang pengelolaan Penyelenggaraan Pendidikan, yang menyebutkan bahwa tujuan penyelenggaraan pendidikan dasar dan menengah yaitu membangun landasan bagi perkembangan potensi siswa agar menjadi manusia yang berilmu, cakap, kritis, kreatif, dan inovatif. 
Didalam kegiatan belajar mengajar, siswa sering menghadapi kesulitan ketika menyelesaikan soal ataupun menghadapi permasalahan yang diberikan oleh guru. Kebanyakan dari siswa hanya akan mengerjakan sama seperti apa yang dicontohkan oleh guru dikelasnya. Ketika soalnya sedikit berbeda penyajiannya, siswa kesulitan untuk menyelesaikan soal tersebut. Pentingnya kemampuan berpikir dalam pembelajaran matematika dilatihkan kepada siswa sebagai usaha peningkatan kualitas sumber daya (Santika, 2016). Meskipun setiap siswa memiliki potensi kreatif, tetapi bagaimanakah caranya untuk mengembangkan potensi kreatif tersebut melalui proses pembelajaran di kelas. Oleh karena itu, diperlukan adanya kemampuan untuk berkreativitas sehingga siswa dapat memilih dan menerapkan permasalahan yang dihadapinya dengan benar dan pada akhirnya hasil belajar yang diharapkan dapat optimal.

Berpikir kreatif adalah kemampuan yang menghasilkan ide-ide atau cara baru dalam menyelesaikan permasalahan yang dapat menunjukkan berbagai variasi jawaban (Octafia, 2018). Kemampuan berpilir kreatif tersebut meliputi kompetensi yang dapat mengajukan ide-ide baru berdasarkan situasi yang diberikan, melengkapi data dalam menyusun masalah, menggambar atau representasi matematik sesuai dengan karekteristiknya, menemukan beberapa cara yang mungkin benar, menyusun kemungkinan-kemungkinan penyelesaian suatu masalah, menyusun pola, dan menentukan banyaknya unsur pada pola tertentu serta menentukan kesimpulan. Siswa tidak hanya diberikan teori- teori atau rumus-rumus matematika saja, tetapi siswa dilatih dan dibiasakan untuk belajar memecahkan masalah sehingga pemahaman siswa terhadap suatu konsep menjadi lebih bermakna.

Kemampuan berpikir kreatif berperan penting bagi kelangsungan kehidupan manusia dan tidak hanya berguna dalam bidang matematika saja, namun sangat berguna dalam bidang lainnya. Perkembangan optimal dari kemampuan berpikir kreatif berhubungan erat dengan bagaimana cara mengajar guru dikelas. Namun, fokus dan perhatian pada upaya peningkatan kemampuan berpikir kreatif dalam pembelajaran matematika masih jarang sekali dikembangkan. Kemampuan ini (berpikir kreatif) dalam konteks pembelajaran matematika, adalah kemampuan yang merangsang siswa untuk menemukan solusi yang beragam dari kemampuan 
berpikir siswa (Ryan W. S., 2014). Siswa dituntut untuk tidak lagi terbatas pada pemikiran yang konvergen melainkan pemikiran yang divergen karena setiap siswa memiliki kreativitas yang berbeda-beda (Wilda et al., 2017). Siswa dengan daya kreativitas yang tinggi akan mampu belajar dengan baik karena dia selalu mempunyai ide-ide yang kreatif yang dapat meningkatkan motivasi belajarnya serta akan selalu berusaha menemukan sesuatu yang baru dalam hidupnya.

Dalam proses pembelajaran, seorang guru memiliki peran penting dalam menentukan kualitas (Sukriyati, 2012). Oleh karena itu, sebelum memulai pembelajaran seorang guru harus merencanakan proses pembelajaran secara sistematis agar tujuan pembelajaran yang diharapkan dapat tercapai. Salah satu alternatif yang dapat menutupi kelemahan-kelemahan pembelajaran di atas adalah dengan menerapkan pembelajaran kooperatif (cooperative learning) yang saat ini banyak digunakan untuk mewujudkan kegiatan belajar mengajar siswa yang berorientasi kepada siswa (student oriented), terutama mengatasi permasalahan yang ditemukan guru dalam mengaktifkan siswa yang tidak dapat bekerja sama dengan orang lain, siswa yang agresif dan tidak peduli pada yang lain. Model pembelajaran harus mampu memberikan kemudahan belajar kepada siswa dengan suasana gembira, penuh semangat dan berani mengungkapkan (Mailili, 2018). Salah satu model pembelajaran kooperatif yang dimungkinkan mampu menutupi kelemahan model pembelajaran konvensional adalah model pembelajaran kooperatif tipe Student Teams Achievement Divisions (STAD).

STAD adalah pembelajaran kooperatif menggunakan kelompok-kelompok kecil dengan jumlah tiap anggota kelompok 4-5 siswa secara heterogen. Pembelajaran STAD diawali dengan penyampaian tujuan pembelajaran, penyampaian materi, kegiatan kelompok, kuis, dan penghargaan kelompok (Trianto 2007). Dalam kegiatan pembelajaran model STAD, terjadi interaksi antara siswa dengan siswa, interaksi antara guru dengan siswa, maupun interaksi antara siswa dengan sumber belajar. Model pembelajaran kooperatif tipe STAD adalah salah satu model pembelajaran yang berguna untuk menumbuhkan siswa untuk mempunyai kemampuan kerja sama, kreatif, berpikir kritis dan ada kemampuan untuk membantu teman serta merupakan pembelajaran kooperatif yang sangat sederhana (Karmila \& Ekawati, 2016). 
Hasil penelitian Khairina menyebutkan bahwa model pembelajaran kooperatif tipe STAD sangat baik diterapkan pada materi yang tidak hanya memuat materi perhitungan tetapi juga materi yang menuntut penalaran sehingga dapat memunculkan pertanyaan dan menuntut siswa untuk lebih aktif, kreatif dan kritis dalam pembelajaran. Salah satu materi yang cocok diterapkan dengan model pembelajaran kooperatif tipe Student Team Achievement Division (STAD) adalah materi segi empat. Kemampuan berpikir kreatif matematika siswa yang bejumlah 37 siswa di kelas VII-C MTs Al-Washliyah Kolam yang diajar dengan model pembelajaran kooperatif tipe Student Team Achievement Division (STAD) pada materi segi empat mengalami peningkatan setelah diberikan perlakuan.

Melalui hasil penelitian tersebut yaitu pembelajaran yang menggunakan model kooperatif tipe STAD diharapkan mampu menumbuhkan kerja sama tim dalam kelompok, meningkatkan keaktifan siswa, siswa mampu menyampaikan ide-ide atau gagasan yang berhubungan dengan materi yang sedang dipelajari, sehingga dari sini siswa mampu mengembangkan kemampuan berpikir kreatif matematik.

Menyadari akan hal itu, peneliti melakukan penelitian dengan menerapkan model pembelajaran yang dipadukan dengan pendekatan yang diharapkan efektif dalam pembelajaran matematika. Peneliti memprediksi bahwa model kooperatif tipe STAD cukup efektif diterapkan dalam pembelajaran matematika. Guru diharapkan dapat mengembangkan pembelajaran sesuai dengan kompetensi yang harus dikuasai, mampu menumbuhkan kreativitas dan dapat mengembangkan sikap sosial diantara siswa. Pembelajaran yang menarik dan menyenangkan membuat siswa tidak merasa bosan serta tertantang untuk belajar.

Berdasarkan uraian di atas, peneliti berkeinginan untuk mendeskripsikan tingkat kemampuan berpikir kreatif (TKBK) pada materi segiempat siswa kelas VII SMPN 1 KRAMATWATU. Penelitian ini diharapkan dapat memberikan deskripsi tentang tingkat kemampuan berpikir kreatif sehingga dapat membantu guru maupun sekolah dalam memperbaiki dan merencanakan pembelajaran agar lebih memperhatikan tingkat kemampuan berpikir kreatif masing-masing siswa.

Diharapkan dengan kegiatan ini siswa dapat menemukan sendiri konsep-konsep pada materi segiempat dan segitiga dengan model pembelajaran kooperatif tipe Student Teams Achievement Divisions (STAD) dan dapat mengaplikasikannya 
dalam kehidupan sehari-hari. Karena berdasarkan keterangan di lapangan bahwa SMPN 1 KRAMATWATU belum pernah menggunakan model pembelajaran kooperatif tipe Student Team Achievement Division maka dalam penelitian ini peneliti menerapakan model pembelajaran kooperatif tipe Student Team Achievement Division.

\section{B. Metode Penelitian}

Jenis penelitian ini adalah penelitian quasi eksperiment atau eksperimen semu karena adanya keterbatasan dalam mengontrol faktor-faktor yang mungkin dapat mengintervensi situasi pembelajaran yang dilakukan. Penelitian ini bertujuan untuk meningkatan kemampuan berpikir kreatif siswa melalui model pembelajaran kooperatif tipe Student Teams Achievement Divisions (STAD).

Pengambilan sampel dalam penelitian ini ditentukan dengan menggunakan teknik purposive random sampling. Peneliti dibantu dengan guru mata pelajaran matematika memilih kelas VII D dan VII E sebagai kelas sampel penelitian. Kelas VII-D untuk kelompok Pembelajaran STAD, dan Kelas VII-E untuk pembelajaran konvensional.

Penelitian ini dilaksanakan di SMPN 1 KRAMATWATU yang beralamat di Jalan Raya Cilegon KM.8, Kramatwatu, Kec. Kramatwatu, Serang, Banten. Kegiatan penelitian dilakukan pada semester II Tahun Pelajaran 2019/2020, Penetapan jadwal penelitian disesuaikan dengan jadwal yang ditetapkan oleh kepala sekolah. Adapun materi pelajaran yang akan diteliti adalah "Segi Empat" tepatnya luas dan keliling persegi dan persegi panjang.

Desain penelitian yang digunakan pada penelitian ini yaitu Pretest-Posttest Control Group Design. Adapun tabel desainnya adalah sebagai berikut:

Tabel 1. Desain penelitian Pretest - Posttest Control Group Design

\begin{tabular}{cccc}
\hline Kelompok & Pretest & Perlakuan & Posttest \\
\hline Eksperimen & $\mathrm{O}_{1}$ & $\mathrm{X}$ & $\mathrm{O}_{2}$ \\
Kontrol & $\mathrm{O}_{1}$ & - & $\mathrm{O}_{2}$ \\
\hline
\end{tabular}

Keterangan:

$\mathrm{O}_{1}$ : Kemampuan berpikir kreatif sebelum diberi perlakuan (pretest)

$\mathrm{X}$ : Perlakuan pada kelas eksperimen dengan menggunakan model pembelajaran kooperatif tipe Student Teams Achievement Divisions (STAD). 
$\mathrm{O}_{2}$ : Kemampuan berpikir kreatif setelah diberi perlakuan (posttest)

Instrumen penelitian yang digunakan untuk memperoleh data dari penelitian ini adalah Tes Kemampuan Berpikir Kreatif Matematika yang berupa 5 soal uraian. Tes tersebut diberi pada awal (pretest) dan pada akhir pembelajaran (posttest) untuk mengetahui peningkatan kemampuan berpikir kreatif siswa setelah penerapan pendekatan pembelajaran berbasis realistik.

Indikator kemampuan berpikir kreatif pada penelitian ini yaitu,
a) keterampilan berpikir lancar,
b) keterampilan berpikir luwes (fleksibel),
c) keterampilan berpikir orisinal,
d) keterampilan berpikir elaboratif.

\section{Hasil Dan Pembahasan}

Sebelum model pembelajaran Student Team Achievement Division dan STAD) dilaksanakan terlebih dahulu dilakukan pre-tes untuk mengetahui kemampuan awal siswa. Pre-tes yang diberikan kepada siswa berbentuk soal uraian sebanyak 5 soal, siswa kelas eksperimen dengan jumlah siswa 28 orang, pada tes awal diperoleh nilai rata-rata sebesar 17,68 dengan standar deviasi 15,06. Siswa kelas kontrol dengan jumlah siswa 28 orang pada tes awal diperoleh nilai rata-rata sebesar 14,82 dengan standar deviasi 13,01.

Tabel 2. Interval Kriteria Skor Kemampuan Berfikir Kreatif

\begin{tabular}{cccc}
\hline No & Interval Nilai & Persentase & Kategori Penilaian \\
\hline 1 & $0 \leq \mathrm{SKBK}<45$ & $32 \%$ & Sangat Kurang Baik \\
\hline 2 & $45 \leq \mathrm{SKBK}<65$ & $54 \%$ & Kurang Baik \\
\hline 3 & $65 \leq \mathrm{SKBK}<75$ & $14 \%$ & Cukup Baik \\
\hline 4 & $75 \leq \mathrm{SKBK}<90$ & $0 \%$ & Baik \\
\hline 5 & $90 \leq \mathrm{SKBK}<100$ & $0 \%$ & Sangat Baik \\
\hline
\end{tabular}

Keterangan : SKBK = Skor Kemampuan Berpikir Kreatif

Dari tabel distribusi data kelompok diatas, kemampuan berpikir kreatif matematika siswa yang diajar dengan model pembelajaran kooperatif tipe Student Team Achievement Division diperoleh bahwa: siswa yang memperoleh nilai dengan kategori Sangat Kurang Baik sebanyak 9 orang siswa yaitu 32\%, siswa pada rentang ini siswa belum mencapai indikator kemampuan berpikir kreatif. Kategori Kurang Baik sebanyak 15 orang siswa yaitu 54\%, demikian siswa pada rentang ini 
siswa hanya dapat mencapai satu indikator kemampuan berpikir kreatif. Kategori Cukup Baik sebanyak 4 orang siswa yaitu 14\%, pada rentang ini siswa mampu menuliskan banyak cara dalam menjawab soal pada materi segi empat, siswa mampu menyelesaikan soal lebih dari satu jawaban, siswa mampu menjawab soal secara beragam atau bervariasi pada materi segi empat, tetapi siswa kurang mampu mengembangkan atau memperkaya gagasan jawaban suatu soal, siswa kurang mampu memberikan cara penyelesaian lain dari yang sudah ada pada materi segi empat.

Sesuai dengan kriteria ketuntasan, bahwa suatu pembelajaran dipandang telah tuntas jika terdapat $80 \%$ siswa yang telah memiliki skor $\geq 65$ dari skor maksimum. Dengan demikian kemampuan berpikir kreatif matematika siswa yang diajar dengan model pembelajaran kooperatif tipe Student Team Achievement Division belum memenuhi kriteria ketuntasan.

Setelah diketahui kemampuan awal siswa, selanjutnya siswa kelas eksperimen diajar dengan menggunakan model pembelajaran kooperatif tipe Student Team Achievement Division (STAD). Pada pertemuan terakhir, siswa diberikan post -tes untuk mengetahui hasil tes kemampuan berpikir kreatif siswa sebanyak 5. Adapun sampel pada penelitian ini adalah siswa kelas VII-D SMPN 1 KRAMATWATU. Jumlah sampel pada kelas eksperimen adalah 28 orang. Untuk menghitung nilai rata-rata, seluruh nilai siswa dibagi dengan jumlah sampel sehingga rata-rata yang diperoleh adalah 44,46, dengan standar deviasi 17,55, nilai maksimum 70 dan nilai minimum 10 .

Adapun data hasil pos-tes untuk kelas eksperimen dan kelas kontrol dapat dilihat pada tabel 3 berikut ini:

Tabel 3. Ringkasan Nilai Kelas STAD dengan Kelas Konvensional

\begin{tabular}{ccc}
\hline Statistik & $\begin{array}{c}\text { Kelas STAD } \\
\text { (Kelas VII D) }\end{array}$ & $\begin{array}{c}\text { Kelas Konvensional } \\
\text { (Kelas VII E) }\end{array}$ \\
\hline Jumlah Siswa & 28 & 28 \\
\hline Jumlah Soal & 5 & 5 \\
\hline Jumlah Nilai & 1245 & 810 \\
\hline Rata-rata & 44,47 & 28,93 \\
\hline Standar Deviasi & 17,55 & 14,23 \\
\hline Varians & 308,04 & 202,51 \\
\hline Nilai Maksimum & 70 & 60 \\
\hline Nilai Minimum & 10 & 5 \\
\hline
\end{tabular}


Berdasarkan tabel 3, diketahui bahwa rata-rata nilai kelas eksperimen lebih tinggi dari rata-rata nilai kelas kontrol yaitu 44,47 di kelas eksperimen dan 28,93 di kelas kontrol. Nilai maksimum di kelas eksperimen adalah 70 dan nilai minimumnya 10, sedangkan di kelas kontrol nilai maksimumnya adalah 60 dan nilai minimumnya 5 .

Dengan demikian dapat disimpullkan bahwa terdapat perbedaan kemampuan berpikir kreatif matematika siswa yang diajar dengan pembelajaran kooperatif tipe STAD dan siswa yang diajar dengan pembelajaran konvensional. Dimana diketahui bahwa penggunaan model pembelajaran kooperaatif tipe STAD memiliki pengaruh yang positif terhadap kemampuan berpikir kreatif matematika siswa. Hal ini terbukti dari nilai rata-rata hasil belajar siswa dilihat dari kemampuan berikir kreatif matematika siswa dengan model pembelajaran Student Team Achievement Division (STAD) lebih baik dibanding dengan nilai rata-rata siswa yang diajar dengan model pembelajaran konvensional.

\section{Kesimpulan}

Berdasarkan hasil analisis dan pembahasan yang telah dilakukan, maka dalam penenlitian ini diperoleh kesimpulan bahwa peningkatan rata-rata kemampuan berpikir kreatif matematika siswa yang diajar dengan pembelajaran model Student Teams Achievement Divisions (STAD) lebih baik dari pembelajaran konvensional. Rata-rata hasil belajar matematika siswa yang diajar menggunakan model Student Teams Achievement Divisions lebih rendah dari pada KKM. Nilai rata-rata kemampuan berpikir kreatif siswa pada materi segiempat adalah 44,47 dari skor ideal 100 serta hasil rata-rata persentasenya adalah $44 \%$ berada pada kategori kurang kreatif artinya masih banyak siswa yang belum mampu untuk berpikir kreatif dalam memecahkan masalah pada materi segiempat.

\section{Daftar Pustaka}

Chaeriyah, S. (2010). Penerapan Model Pembelajaran Kooperatif Tipe Student Teams-Achievement Divisions (STAD) Untuk Meningkatkan Kemampuan Pemecahan Masalah Matematika Siswa Kelas VII D SMP Negeri 2 Depok Pada Materi ). Bangun Segiempat. 
Karmila, K., \& Ekawati, D. (2016). EFEKTIVITAS PEMBELAJARAN MATEMATIKA MELALUI MODEL KOOPERATIF TIPE STAD DENGAN PENDEKATAN PROBLEM POSING. Pedagogy: Jurnal Pendidikan Matematika, 1(2), 76-85.

Khairina, N. (2018). Perbedaan Kemampuan Berpikir Kretaif Matematika Siswa Yang Diajar Dengan Model Pembelajaran Kooperatif Tipe Student Teams Achievement Division (STAD) Dan Team Quiz Pada Materi Segi Empat di Kelas VII MTs Al-Washliyah Kolam Tahun Pelajaran 2017/2018 (Doctoral dissertation, Universitas Islam Negeri Sumatera Utara).

Mailili, W. H. (2018). EFEKTIVITAS PEMBELAJARAN QUANTUM LEARNING TERHADAP HASIL BELAJAR MATEMATIKA SISWA PADA MATERI SEGIEMPAT DAN SEGITIGA. Pedagogy, 3(1), 51-60.

Octafia, Y. Profil Berpikir Kreatif Siswa dalam Menyelesaikan Soal Segiempat dan Segitiga. UNIVERSITAS JEMBER.

Rohmawati, A. (2018). Pembelajaran Matematika dengan Menggunakan Model Pembelajaran Kooperatif Tipe Student Teams and Division (STAD) dan Think Pair Share (TPS) Ditinjau dari Kemampuan Berpikir Kreatif di SMP Muhammadiyah 1 Kartasura. Electronic Theses and Dissertsion Universitas Muhammadiyah Surakarta.

Ryan W. S., H., Ratu, N., \& Nova H. Y., T. (2014). Deskripsi Tingkat Kemampuan Berpikir Kreatif (TKBK) Pada Materi Segiempat Siswa Kelas VII SMP Negeri 1 Pabelan Kabupaten Semarang Helarius Ryan Wahyu Santoso. Universitas Kristen Satya Wacana, 30(2), 82-95.

Santika, S. (2016). Pengaruh penggunaan pembelajaran kooperatif tipe STAD berbantuan program Geometer' s Sketchpad terhadap kemampuan berpikir kreatif matematik siswa SMP. Jurnal Penelitian Pendidikan Dan Pengajaran MatematikaJurnal Penelitian Pendidikan Dan Pengajaran Matematika, 2(1), 49-60.

Sukriyati, S. M. (2012). Eksperimentasi model pembelajaran kooperatif tipe student 
teams achievement divisions (stad) dilengkapi media cd pembelajaran pada pokok bahasan segitiga dan segiempat ditinjau dari gaya kognitif pada siswa smp/mts di kabupaten grobogan tahun pelajaran (Doctoral dissertation, UNS (Sebelas Maret University)).UNIVERSITAS SEBELAS MARET SURAKARTA.

Putri, M. W. T., \& Ratu, N. (2018). ANALISIS TINGKAT BERPIKIR KREATIF SISWA DALAM MENYELESAIKAN SOAL LUAS GABUNGAN PADA MATERI BANGUN DATAR DI SMP NEGERI 8 SALATIGA KELAS VII. Pendekar: Jurnal Pendidikan Berkarakter, 1(1), 103-109.

Wilda, Salwah, \& Ekawati, S. (2017). Pengaruh kreativitas dan minat belajar terhadap hasil belajar matematika siswa. Pedagogy, 2(1), 134-144. 